\title{
Comparison of propagation methods of different moss species used as wall and ground covering ornamental plants
}

\author{
Ónody, É. ${ }^{1}$, Fülöp-Pocsai, B. ${ }^{1}$, Tillyné Mándy, A. ${ }^{1}$, Papp, B. ${ }^{2}$, Tóth, E. ${ }^{3}$ \& Ördögh, ${ }^{1}{ }^{1}$ \\ ${ }^{1}$ Szent István University, Faculty of Horticultural Science, Department of Floriculture and Dendrology, \\ H-1118 Budapest, 29-43. Villányi str., Hungary,E-mail:eva.onody@gmail.com \\ ${ }^{2}$ Hungarian Natural History Museum, Bryological Collection, H-1087 Budapest, Könyves Kálmán Krt. 40. \\ E-mail:pappbea@nhmus.hu \\ ${ }^{3}$ Szent István University, Faculty of Horticultural Science, Department of Botany, \\ H-1118 Budapest, 29-43. Villányi str., Hungary, E-mail: toth.endre@kertk.szie.hu
}

\begin{abstract}
Summary: mosses are traditionally used as ornamental plants, especially in Japan, USA, England (moss gardens) and Germany, French (green roofs). In shadow areas (where the members of Poaceae usually cannot grow well), mosses are potentially use as "grass". The stocks of moss colonies maintain optimal microclimate and decrease desiccation of soils (like mulch). Additionally, mosses are evergreen, attractive all year, during winter. In our study, 18 moss species were propagated by fragments (as mixture, with the use of 16 species) and transplantation of carpets (with Brachythecium rivulare and Calliergonella cuspidata) in Szentendre. The aim was to find the most durable species and the best way of propagation. In an outdoor, irrigated garden, propagation by fragments was effective (with $63 \%$ coveration) and higher values (93\% and $76 \%$ ) were obtained in the cases of non-irrigated stocks of Amblystegium serpens (in trays) and moss carpets. In vertical structures (moss picture-frames with the use of mixtures), protonema of 2 species (Hypnum cupressiforme and Eurhynchium hyans) covered 24 and $33 \%$ of the $0.5 \times 0.5 \mathrm{~m}$ sized area.
\end{abstract}

Keywords: coveration, moss carpet, moss mixture, propagation, protonema

\section{Introduction}

Since hundreds of years, mosses have used as ornamental plants in Japan. Furthermore, mosses (e.g. Sphagnum) are suitable as toxic metal $(\mathrm{Ag}, \mathrm{Cu}, \mathrm{Cd}, \mathrm{Hg}, \mathrm{Fe}, \mathrm{Sb}, \mathrm{Pb})$ indicators and they are using as water purifier because these plants filters out contaminants like detergents, paints and microorganism. Other (hydrophobic) mosses adsorbs oils. Some species are useful as herbs, and during pest control researches certain mosses became more and more important (Saxena, 2004).

Marchantiophyta, Hepaticophyta and Bryophyta mosses are excellent indicators to show changes of environmental conditions. Because of the absent of epidermis and cuticle layer, these plants are very reactive to air pollution, acid rain. In order to examine water pollution and $\mathrm{Ca}$-, nutrition levels, water moss species can be used. Others highly adapted to limited $\mathrm{pH}$ ranges of soils, so these specialized mosses indicates $\mathrm{pH}$ level changes. Some of them used as sensitive bioindicators of air quality, and by the help of these mosses, IAP (index of atmospheric purity) can be determined as well (Kremer and Muhle, 2000; Saxena, 2004).

In some cases, studies of mosses (as plants of green roofs) were carried out. Due to their low weight, mosses are excellent for weak building structures. The weight of a 3-4 $\mathrm{cm}$ thick carpet of mixed moss + Sedum is only $30-40 \mathrm{~kg} /$ $\mathrm{m}^{2}$ (Minke, 2009). In West European countries, mosses were used as green roof for hundreds of years. Mosses and lichens need not (or less) soils, so usage of these organism decrease the costs of roof-building. A special medium supplemented with cement (copyrighted by Fentiman Consulting) increase developments of mosses. Panels of these extensive green roof will probably useful for different kinds of buildings and moss species can easily choose in according to the environmental conditions in order to enhance biodiversity (Grant, 2006).

BRYOTEC Technology is a patented invention by MCK Environnement (French). It is a biological inoculant (containing bryophytes and microorganism with high productivity level) that produces crust of mosses. This living layer is important for ground stabilization (e. g. on the roof), carbon and nitrogen fixation and BRYOTEC Technology offers all criteria to develop a mossy cover rapidly (3-6 weeks in humid, mild climate). There are numerous availabilities of this special product: covering extensive green roofs or vertical green walls, restoration of disturbed natural environments (revegetation), reconstitution of forest dynamics in clumps and biomonitoring (Chiaffredo, 2004).

In the 1990s, Behrens Systemtechnik (a German company) created special moss roof mats to alternate expensive, heavier 
slate roofs. Only few durable species like Tortula muralis, Ceratodon purpureus and Bryum argenteum are naturally occurs in central, highly air-polluted parts of large towns (e.g. anywhere in central district of London) although acid rains with sulphuric acid damage both limestone walls and mosses on its surfaces. In cleaner city-regions, other moss species, mainly Grimmia pulvinata or sometimes Orthotrichum diaphanum and Schistidium apocarpum appears horizontally or vertically on natural (rocks, trunks) and artificial surfaces like asphalt, cement (Fletcher, 1991).

Bonsai (small trees in small pots) and cup gardens show miniature versions of the nature. Quality of pots, decoration accessories (soils, rocks) and the features of underwood, ground-covering plants (e. g. moss) are as important just like the main plant (bonsai tree). Mosses are useful and attractive ground-covering plants which inhibit soil erosion and maintain moisture (Csaba, 1990). The most famous moss gardens were established in Kyoto (surrounded with mountains), where the climate is optimal. Here, commonly used species are Polytrichum communae, Leucobryum bowringii, L. neilgherrense, Trachycistis microphilla, Rhizogonium dozyanum and (in drier regions) Hypnum plumaeforme and Raconitum canescens (Ando, 1987).

In order to create large, horizontal colonies of mosses (growing as grass or lawn), adaptable species can be used like Brachytecium rutabulum, Eurhynchium praelongum, Rhytidiadelphus squarrosus. Tortula muralis is a good choice to covering walls, such as Bryum argenteum and Barbula species (B. unguiculata, B. convoluta, B. cylindrica, $B$. fallax) in the case of settling onto the pathways. Most of all, $\mathrm{pH}$ level is an outstanding factor. Approximately 5.5 is ideal, and $0.12 \mathrm{~kg} / \mathrm{m}^{2}$ sulphur powder (or buttermilk) can be applied (Schenk, 1997). Glime (2007) suggested a buttermilk + water solution in 1:7 ratio applying twice a day until 2 weeks, during spring.

Generally, mosses need not fertilization, nevertheless nutrient solutions can be added if it necessary. In special cases and places (when or where neither wind nor rain cannot give enough organic materials containing essential elements), Rhododendron-fertilizers (in dilution 10\%) is recommended bimestrial, excepting winter (Glime, 2007).

Mosses cannot tolerate tap water. Different ions (especially $\mathrm{Ca}^{2+}, \mathrm{Mg}^{2+}$ ) of this water are toxic for $95 \%$ of the moss species (Smith, 2010). About the number of irrigation, too much desiccation is the worst for mosses. A long, dry period is better, because these plants can easily regenerate themselves after one rest, while in the case of several dry season with unfavourable shorter regeneration, mosses cannot produce new cells and organs. Irrigation is necessary during propagation or when new colonies are settled. Continuous wetting of newly planted (adult) colonies is as important as in the case of fragmented specimens (Glime, 2007).

Weeds often inhibit mosses, especially during spring. On the other hands, grasses (Poaceae) are not so dangerous (mainly shaded areas, these plants usually cannot endangered mosses), and even, this monocotyledonous plants generate optimal microclimate until full growth of mosses.
Advantageously, moss carpets need not mowing although clearing is problematic. In most cases, hand weeding is the only way. Total herbicides are rarely used, but before use weedicides, mosses need large quantity of irrigation (Schenk, 1997; Smith, 2012).

Moles, crickets, ants and slugs often damage moss gardens (Ando, 1987), sometimes isopods (Glime, 2007), squirrels and mainly (70\%) birds caused problems with drilling, digging and punching (Smith, 2012).

Mosses can propagate by generative and vegetative methods. The first is extremely elaborate and slow, because it is very difficult to collect enough spores and its germination is usually heterogeneous. Asexual propagations (see below the 2 main group) are much reliable, simpler and cheaper than spore-sowing (Smith, 2012).

\section{Propagation by fragments}

Cutting of fragments is a common way of vegetative moss propagation. If the conditions are optimal, protonema and (later) mature moss plants regenerate well from these fragments. The high ability of fragment regeneration allows easy and fast vegetative propagation (Orbán, 1999; Fodorpataki and Szigyártó, 2008). In Japan, chopped fragments are directly planted (as cutting method), or (as another process) these small parts are diffused and thereafter covered with thin layer of soil (for propagation by fragments, $60 \times 30 \mathrm{~cm}$ sized plastic tray are commonly used). In this country, the most popular (and marketable) species is Polytrichum communae, which can be ready to sell only in 3 months after propagation (Ando, 1987).

In greenhouse, Tortula ruralis moss fragments were diffused and covered with $1 / 2 \mathrm{~cm}$ layer of lime rich rendzina soil, and irrigated regularly/weeks. After about 5 months, colonies were completely grown up (Olasz, 1989).

Special mass (contained with $0.9 \mathrm{~L}$ soil-mixture, 0.8 L distilled water, 2 L moss fragments, 200-500 piece of sporophyte) was filled in trays. During growing period, stocks were lighted 10 hours/day with light bulbs $(60 \mathrm{~W})$. As planting soil, sterile Eco Compost was used. In order to maintain optimal moisture, trays were covered by foil and irrigated with distilled water as needed. The first protonema was appeared approximately 30 days and the first adult moss plants were developed 60 days after starting. After the last frost days in spring, trays were transferred out (in shaded area) and finally, moss colonies were planted out after 1214 months from propagation. Every mosses (Hylocomium splendens, Rhytidiopsis robusta, Dicranum scoparium and Mnium lycopodiodes) were propagated successfully with this method but the first two species grown better (McDonough, 2006).

In another propagation study (Glime, 2007), sawdust (as soil) was covered by easy cotton textile and moss fragments were diffused on the surface of this fabric. For adjusting $\mathrm{pH}$, milk (or powdered milk) + water combination (in ratio 1:7) was used and after it, fragments were covered by the second layer of cotton. After about 4.5 months, all structure 
were easily moved and planted out. For the best and fastest growing, $20^{\circ} \mathrm{C}$ and 8 hour/day lighting (with luminance 900 lx) was optimal. This propagation way was the most efficient in the case of Brachytecium és Plagiomnium species.

Mosses are propagated by fragments, if moss mixtures are prepared. As this method, mashed combinations of dried mosses, beer/curd cheese or yoghurt and water are glazed on artificial surfaces. It is a soilless construction (moss mat system) with 3 layer and without desiccation. The lowest layer is a plastic foil (which separate upper layers from the soil). As the middle part of this system, 2-3 layer of hygroscopic landscape fabric (geotextile) is used. On this felt surface, mosses can take enough moisture for their life. And last (as the third main part), mosses are covered by tulle in order to avoid damages caused by pests (mainly birds) and contrarious (Smith, 2012).

\section{Transplanting of moss carpets (full-grown moss colonies)}

Transplanting of adult moss colonies is efficient way to establish moss gardens if the growing conditions (humidity, temperature etc.) are ideal. Disadvantageously, this method is accomplishable for only smaller places, because large quantity of colonies is necessary for establishing moss grasses (Fletcher, 1991; Smith, 2012).

Successful division and transplanting of colonies (onto loamy soil) was done in the case of Amblistegium serpens, Atrichum undulatum, Brachitecium salebrosum, Bryum argenteum, Ceratodon purpureus, Funaria hygrometrica, Hypnum cupressiforme, Pohlia cruda. In another trial, Dicranella heteromalla, Dicranum scoparium, Climacium dendroides and Polytrichum juniperum colonies were placed on brown forest soil (with few quantity of loam) and irrigated weekly. As it turned out, almost every species (except Amblystegium serpens, Climacium dendroides, Polytrichum juniperum) completely grew up in 5-7 months, and the colonies fully covered the studied area (Olasz, 1989).

As usual in Japan (the motherland of the oldest moss gardens), mature moss carpets cut into $20 \times 20 \mathrm{~cm}$ parts and repose in check pattern (Glime, 2007). According to Schenk (1997), it last 2-3 years as long as Polytrichum moss colonies will attain full growth, although certain mosses (like the horizontally structured Brachytecium) need only 1 year for full covering.

\section{Material and methods}

\section{Collecting of mosses}

Mosses were originated from 2 places, Bükkös and Tahitótfalu.

Almost every moss species were collected (by hand or sometimes with the use of knife) near Bükkös in March 2013. The estuary part of this $16 \mathrm{~km}$ long brook can be found in Szentendre, and in the city, this watercourse flews in artificial bed. Here, the climate is semi-arid (east and west sides) and cooler, semi-humid (main place of our research) with an average of just 1900 hours of sunshine a year. The average yearly temperature is not more than $8{ }^{\circ} \mathrm{C}$ at the peak of Dobogókő and between $9.5-10^{\circ} \mathrm{C}$ at the base part. During vegetation period, the average temperature is $14-16{ }^{\circ} \mathrm{C}$ (upper parts: cooler, below: warmer). Annual precipitation is about $580 \mathrm{~mm}$ at the base parts and $750 \mathrm{~mm}$ at the peak (in vegetation season, rainfall values changes between 320 and $420 \mathrm{~mm}$ ). The main direction of wind is northwest (Dövényi, 2010).

The weight of moss-samples (in the case of all, 16 species from Bükkös) was approximately $50 \mathrm{~g}$ and all of them were packed in paper bags. Hypnum cupressiforme and Eurhynchium hians were mostly found. The first is a cosmopolite species, occurs on several surfaces (bark, rock, forest soils) in large quantities. Highly variable formed and sized moss, produce bright green (sometimes yellowish, brownish and blackish), prostrated or erected stems. E. hians can be found several places (with neutral or alkaline $\mathrm{pH}$ scales) for example on wet soils, in meadows and forests, close to watercourses (and on its banks), by the roadsides, on the surface of rocks and walls. This species has short or medium sized, yellowish or green stems in prostrated, slack colonies (Orbán and Vajda, 1983).

In January 2014, 2 moss species (Brachitecium rivulare and Calliergonella cuspidata) were collected in Tahitótfalu (with similar climate like brook side Bükkös), close to the river Danube. B. rivulare is often find nearby water sources, brooks or on wet rocks and produce incompact, yellowishgreen colonies. Calliergonella cuspidata mainly occurs on lower hills, downs and prefer moist habitats like coast of brooks, humid meadows, moors. It is a green, yellowish or rusty, smoothly branched, erected $(5-15 \mathrm{~cm}$ height) moss without rhizoids (Orbán and Vajda, 1983). Grass-like moss colonies of these 2 species were mostly found in Tahitótfalu (in shade parts of a non-irrigated garden) and $0.4 \times 1.5 \mathrm{~m}$ sized moss carpets were picked up.

\section{Identification of collected mosses}

For precise identification of the collected all (18) species (Table 1), microscopic examination (Figure 1) in the Department of Botany (Corvinus University of Budapest) was done. Additionally, samples of every species were packed in numbered paper bags and handed over to Beáta Papp bryologist (Hungarian Natural History Museum, curator of Bryological Collection), who helped to identify squarely the species. Besides, literatures by Orbán and Vajda (1983), Smith (2000), Papp et al. (2010), Jakab and Sümegi (2011) were used for characterization of species.

\section{Propagation}

Studies were carried out in shade, humid parts of a private garden in Szentendre. 

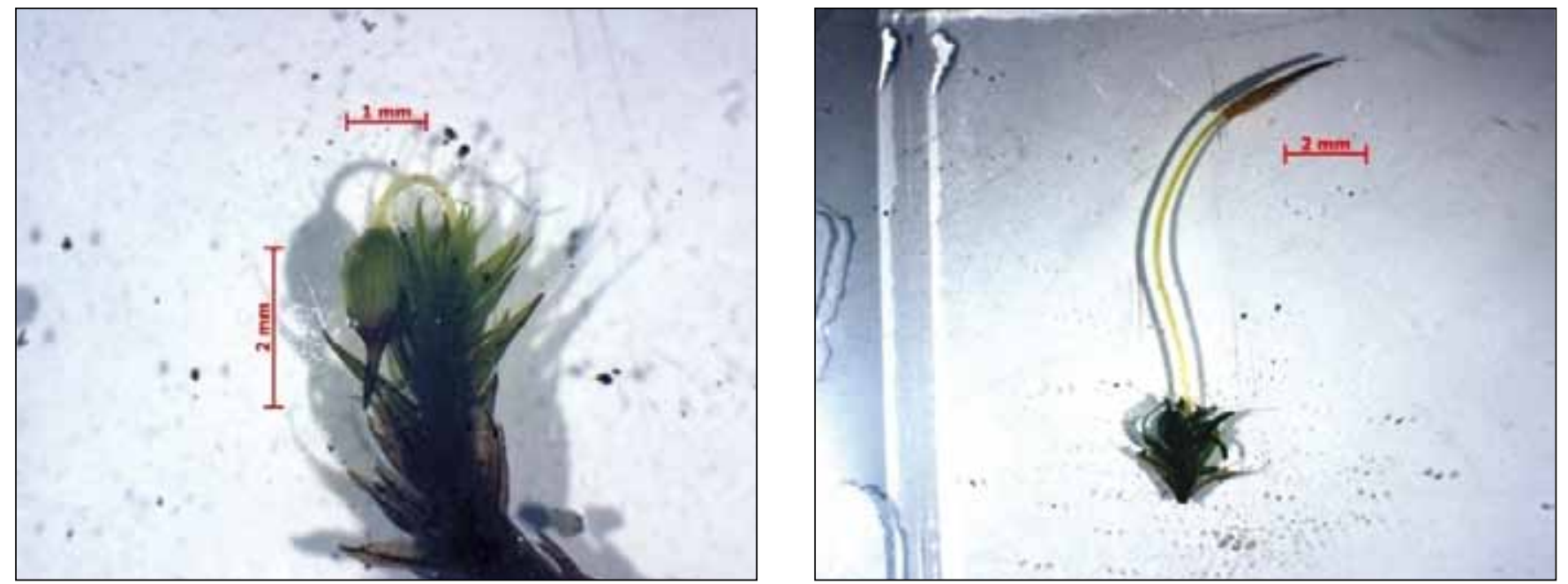

Figure 1. Grimmia pulvinata (left) and Barbula unguiculata (right) (photos by FÜLÖP-POCSAI, 2014)

Table 1. Collected moss species

\begin{tabular}{|l|l|}
\hline \multicolumn{2}{|c|}{ Moss species (from Bükkös) } \\
\hline Amblistegium serpens & Funaria hygrometrica \\
\hline Barbula unguiculata & Grimmia pulvinata \\
\hline Brachitecium populeum & Hypnum cupressiforme \\
\hline Brachitecium rutabulum & Ortotrichum sp. \\
\hline Brachitecium salebrosum & Phascum cuspidatum \\
\hline Bryum argenteum Hedw. & Rhynchostegium sp. \\
\hline Ceratodon purpureus & Schistidium apocarpum \\
\hline Eurhynchium hians & Tortula muralis \\
\hline Moss species (from Tahitótfalu) & \\
\hline Brachythecium rivulare & Calliergonella cuspidata \\
\hline
\end{tabular}

\section{Propagation by fragments}

With the use of 16 moss species from Bükkös, mixtures was prepared as descriptions of Schenk (1997) and Smith (2012). Moss-compositions were different in every (21 kind) mixtures: 16 of them contained only 1 species, one mass consisted a combination of all species, and other 2-2 mixtures included Eurhynchyum hians, Hypnum cupressiforme (the commonest 2 species of Bükkös).

The ingredients of (every) moss mixture:

- $30 \mathrm{~g}$ air-dried moss

- $150 \mathrm{~mL}$ light beer

- 3 g hydrogel

- 500-750 mL well-water

As preparation of mixtures, collected mosses were airdried for 4-6 days. Beside, $3 \mathrm{~g}$ hydrogel was put in $500 \mathrm{~mL}$ well-water for one night and mixed with $150 \mathrm{~mL}$ light beer next day. After this, dried (and chopped) mosses and hydrogelbeer solution were mixed by hand-held blender. In order to create an ideally consisted, spreadable pulp, maximum 250 $\mathrm{mL}$ well-water added again (if it was necessary).
Complete mixtures were placed on 3 areas at 1st August, 2013:

1. Picture-frames. Eurhynchyum hians, Hypnum cupressiforme mixtures were put on home-made, vertically fixed picture-frames. In the case of both species, one-one frame was set outdoor and indoor. The structure of this system was presented on Figure 2. The back of the picture-frames was OSB particle board, which was covered by pond liner and 3 layers of geotextile (these layers was affixed by stapler). As framing, glazed fir wood-slats were used. Moss mixtures were daubed with spoon and paint brush on the top geotextile layer. Some minutes after (as drying), picture-frames were put on their places. These vertically fixed stocks were irrigated and sprayed (with well-water, $\mathrm{pH}=7.5$ ) from the next day after starting.

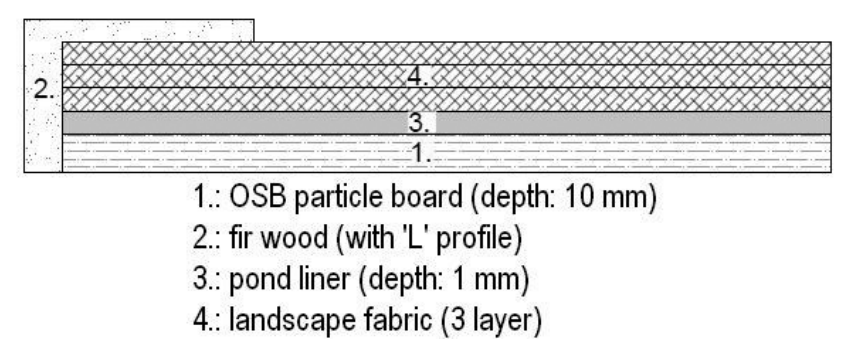

Figure 2. Cross section of moss picture-frames (designed by FÜLÖPPOCSAI, 2014)

2. Propagation trays (with doubling of $1 \mathrm{~mm}$ thick pond liner and 3 layers of geotextile) were also used. 3-4 moss species were planted (as mixtures) in 1 tray and all (16) species were separated by wooden sticks and signed with numbered stones. These stocks were not irrigated.

3. Mixed moss mixture (with a combination of 16 species from Bükkös) was located outside, onto soil surface of a shaded perennial bed. Before smooth placing of the mixture, $1 \times 1 \mathrm{~m}$ area was cleaned, weeded and graded. 


\section{Transplanting of moss carpets (with full-grown moss colonies)}

In February 2014, 0.4 x $1.5 \mathrm{~m}$ sized moss carpets (with Brachitecium rivulare and Calliergonella cuspidata) were deposed onto the test-area in Szentendre. Before placing the carpets, cleaning, weeding and grading was also done. These mosses was irrigated by an automatically controlled drip system (with the use of same water like in the case of picture-frames).

\section{Evaluation}

Samples were photographed and after the adjustment of optimal scales, quadrats were inscribed with software AutoCad 2014. In the case of picture-frames and propagation trays, $1 \mathrm{x} 1 \mathrm{~cm}$ sized scales were made and $1 \times 1 \mathrm{~m}$ sized area of moss carpets was segmented with $5 \times 5 \mathrm{~cm}$ sized units (Figure 3A). Covered areas were coloured in order to determine coveration exactly (Figure 3B).

\section{Results}

\section{Propagation by fragments}

\section{Mosses on picture-frames}

Because of the heat during August 2014, spraying was needed regularly (5-6 times/day). Indoor placed pictures were dried in no time, while the others (outdoor, in the garden) remained wetter during the evenings and if the weather was cooler. For the end of September, down parts of the cultures became green (primary structures, protonema was found here) but further development of mosses was not detected.

Percentage of protonema-coveration was determined only in the case of outdoor moss-pictures. Hypnum cupressiforme and Eurhynchium hyans covered 33 and $24 \%$ of the represented, $0.5 \times 0.5 \mathrm{~m}$ sized area (Figure 4A and 4B).

Represented area: $0.5 \times 0.5 \mathrm{~m}$

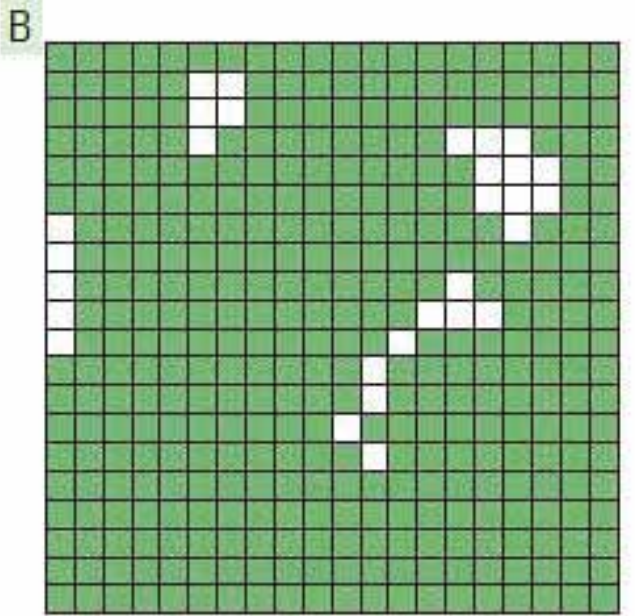

Figure 3. As data's evaluation, quadrats including $1 \times 1$ or $5 \times 5 \mathrm{~cm}$ sized scales were designed (A), and covered areas were coloured for precise determining of coveration $(\mathbf{B})$

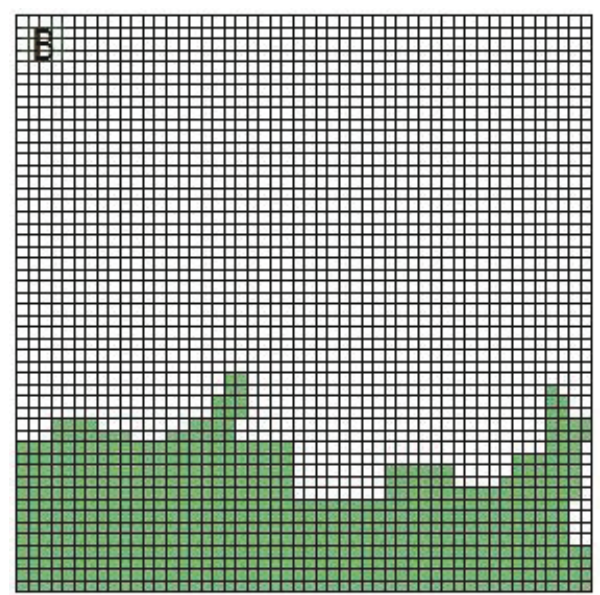

Figure 4. Covered area of protonema of Hypnum cupressiforme $(33 \%$, A) and Eurhynchium hyans $(24 \%$, B).

\section{Mosses in trays}

Coveration-values were calculated with smaller (15 $\mathrm{cm} \times 22 \mathrm{~cm}$ ) area, which turned on the size of trays. Only Amblystegium serpens produced large colonies with 93\% coveration. Unfortunately, slugs damaged almost all mosses by September 2014 .

\section{Mixed moss mixture (in perennial bed)}

Because of the mild winter and drip irrigation, health and adult colonies were developed (Figure 5). After 2 months of moss mixtures settling, the coveration ratio was $63 \%$ (Figure 6A). Considering all moss species of mixture (with different requirements), Amblystegium serpens, Barbula unguiculata, Brachythecium rutabulum, Eurhynchium hians, Phascum cuspidatum produced stronger, larger colonies.

\section{Transplanting of moss carpets}

The first perennial weeds (which eventually transported with the carpets) were found in early spring (2014) although 
in the original area (Tahitótfalu), weeds were not appeared overly, probably by reason of non-irrigation. In the place of the trial (in Szentendre), regular watering increased weed production and different kind of weeds were found here, especially Bellis perennis, Achillea millefolium, Potentilla repens, Plantago major. Another differences were detected between the original and new habitat. In Tahitótfalu (2014 May), thick colonies with strong, large, pale, yellowishbrown parts were found, while thinner groups of smaller, more fragile, dark green segments were developed in Szentendre. By autumn 2014, moss-coveration of the $1 \mathrm{~m}^{2}$ sized represented area was $76 \%$ (Figure 6B).

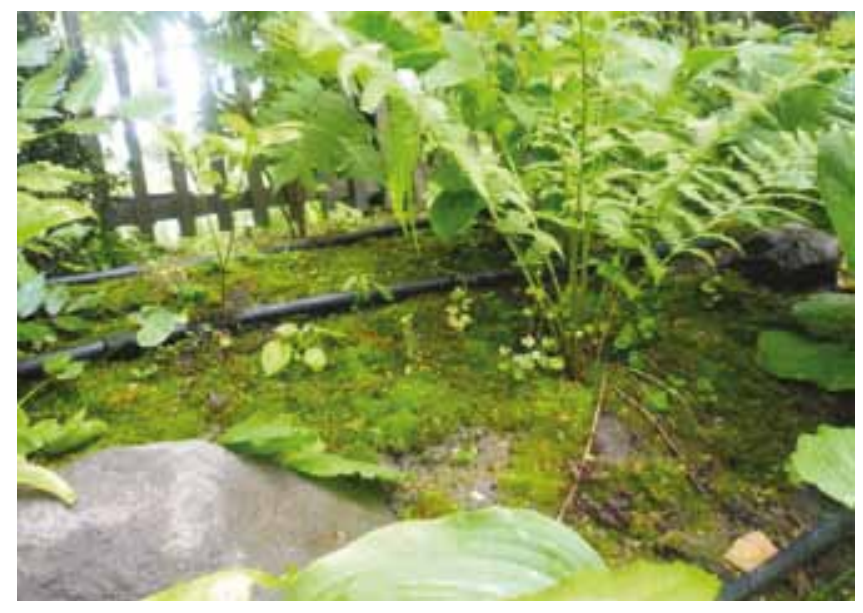

Figure 5. Moss-colonies from mixed mixture with 16 species (photo by FÜLÖP-POCSAI, 2014)
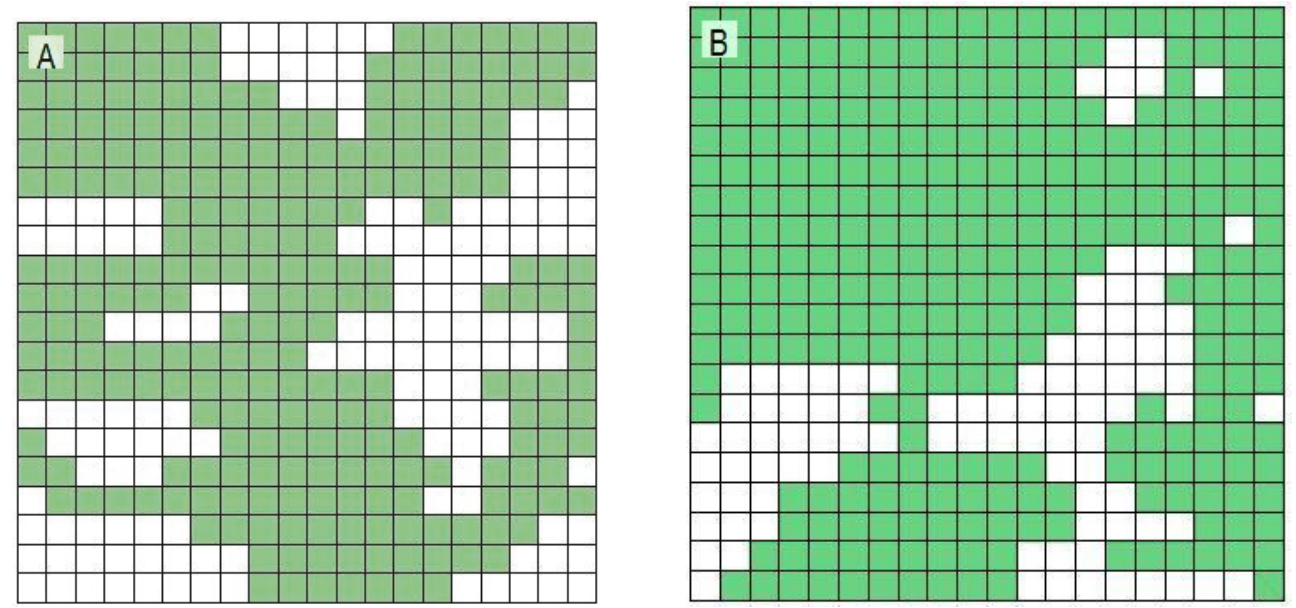

Figure 6. Covered area of perennial bed-mosses (from 'mixed' mixture including 16 species, 63\%, A), and moss carpets (with Brachythecium rivulare and Calliergonella cuspidata, 76\%, B). Represented area: 1 x $1 \mathrm{~m}$ moss wall, young stocks should be cultured horizontally first time, and vertically only after full growth. Another (but expensive) version is the use of automatic irrigation system (at least until the final development of plants). Although younger moss-structures need more humidity, later, irrigation must done with correlation of the waterrequirement of species. In the case of full-grown colonies, less watering (e.g. in extensive cultures and/or during rest periods) is possibly sufficient. Frequency of drying and rewetting is important. After desiccation, minimum 24 hours is needed for successful regeneration of tissues. Mosses can survive long dry seasons if the occurrence is low, but serial desiccations strongly eliminate efficiency of regeneration. Thus, rather frequency than length of dry periods influence viability of mosses (Glime, 2007).

In according to our experiences, irrigation of mosspictures was difficult during summer (because of the high temperatures), this period was not optimal for these cultures. Mosses usually prefer lower temperatures (sometimes the optimum is only $10^{\circ} \mathrm{C}$ ), anyway, these plants often grown better on $20{ }^{\circ} \mathrm{C}$ than in warmer conditions (Glime, 2007). In the case of most species, the maximum temperature of compensation is $20-25{ }^{\circ} \mathrm{C}$ (warmer values eliminate photosynthetic activity - Orbán, 1999), and $40{ }^{\circ} \mathrm{C}$ causes devastation (Bodorné, 2010). Furthermore, temperature of mosses is usually warmer (sometimes $+10{ }^{\circ} \mathrm{C}$ ) than their environment, and irrigations easily effect health damage (especially during hot summer).

We experienced that the attack of the slugs was more serious if mosses (developed from mixture) were cultured in trays, although transplanted moss carpets were not damaged. Presumably, beer (once of the ingredients of moss mixtures in our trial) attracted these pests. To avoid this problem, we can replace beer by yogurt or buttermilk (SMITH, 2012).

\section{Transplanting of moss colonies}

Lifting of carpets was easily done because of the rainy weather and softened soil, although during this procedure, using knife was worked not so well due to this procedure's slowness and elaborateness. Sometimes, mosses were stuck in moisty, clammy soil during flattening (after planting). Thus, drier temperature is better for transplanting. Furthermore, drought tolerant and/or acrocarp mosses with dense, compact colonies are rewcommended (probably these species can also bear treading).

Newly transplanted moss carpets need continuous wetting (the same as in the case of moss fragments). The time vertically fixed constructions. For successful creating of probably water flowed down to the deeper places on these

\section{Propagation by fragments}

In our study, moss-development was not equable on picture-frames (only protonema was found at the base parts), vertically fixed constructions. For successfil creating of 
(February, 2014) of carpet-planting was ideal because of the humid, vaporous and soft weather (note: winter of 2014 was considerably moderate), so mosses were acclimatized more easily.

Mosses have pests, as always all plants. Mostly birds, sometimes rodents (e.g. squirrels) caused problems (Smith, 2012), and similar experiences was obtained in our stocks of moss carpets.

Taking it all round, the following suggestions were presented.

- Much more moss species should be examined, certain species probably grow better in their natural habitat than artificial environments.

- Wider ranges of mosses results higher biodiversity, and the more species are used, the more of them can survive unfavourable conditions, especially on the roofs and walls.

- In the case of vertical cultures (moss picture frames), horizontal siting is recommended until the full growth of mosses.

- For propagation, spring (with cooler daytimes and optimal temperature: $10-20^{\circ} \mathrm{C}$ ) is better season.

- Covering (with foil) is useful to avoid drying and damage of younger moss colonies except during periods with higher temperatures. So as to solve this problem, mosses might shade with black cloth.

- Mostly, mosses need not fertilization, whereas stocks on the roof require more nutrition. Similar responses can find in the case of every (not only sensible but durable) moss species. Supplementation of nutrient solutions possibly help for propagation by fragments and useful for later developments.

- Further trials are suggested to find optimal pH levels of different kinds of natural or artificial soils as to exactly determine the adaptability of mosses.

\section{References}

Ando, H. (1987): Moss gardening in Japan. Symposia Biologica Hungarica. 35: 3-10.

Bodorné, J. A. (2010): Syntrichia ruralis szénmérlege, ökofiziológiai és növekedési sajátosságai száraz homokpusztagyepben, és kriptogám fajok válaszreakciói a növekvő légköri $\mathrm{CO}_{2}$ szintre. Doktori értekezés. Szent István Egyetem, Gödöllö.

Chiaffredo, M. R. (2004): When mosses recreate the landscape on the roof. MCK Environnement and Bryotec Technology, [http:// www.greenroofs.com/archives/gf_feb04.htm]

Csaba, J. (1990): Bonsai. Codex Rt., Budapest

Dövényi, Z. (2010): Magyarország kistájainak katasztere, MTA Földrajztudományi Kutatóintézet, Budapest

Fletcher, M. (1991): Moss Grower's Handbook: An Illustrated Beginner's Guide to Finding, Naming and Growing Over 100 Common British Species. Seventy Press, Berkshire, England

Fodorpataki, L., Szigyártó, L. (2008): A növények szaporodása és a mesterséges növényszaporítás biotechnológiai alkalmazásai. Kolozsvári Egyetemi Kiadó/Presa Universitară Clujeană, Kolozsvár, 244.

Glime, J. M. (2007): Bryophyte Ecology. [www.bryoecol.mtu.edu] Grant, G. (2006): Extesive Green Roofs in London. Urban Habitats. 4 (1): 51-60.

Jakab, G., Sümegi, P. (2011): Negyedidőszaki makrobotanika. GeoLitera SZTE TTIK Földrajzi és Földtani Tanszékcsoport, Szeged.

Kremer, B. P., Muhle, H. (2000): Zuzmók, mohák és harasztok. Természetkalauz. Magyar

McDonough, S. (2006): Moss propagation in Glacier National Park's native plant nursery. Native Plants Journal 7 (1): 27-30.

Minke, G. (2009): Zöldtetők. Cser Kiadó, Budapest

Olasz T. (1989): A mohák, mint dísznövények a kertészetben. Diplomamunka. Kertészeti és Élelmiszeripari Egyetem, Kertészettudományi Kar, Dísznövénytermesztési és Dendrológiai Tanszék, Budapest

Orbán S. (1999): Általános briológia. EKTF Líceum kiadó, Eger

Orbán S., Vajda L. (1983): Magyarország mohaflórájának kézikönyve. Akadémiai kiadó, Budapest

Papp, B., Erzberger, P., Odor, P., Hock, Z., Szövényi, P., Szurdoki, E., Tóth, Z. (2010): Updated checklist and red list of Hungarian bryophytes. Studia Botanica Hungarica 41: 31-59.

Saxena, D. K. (2004): Uses of bryophytes. Resonance 9 (6): 56-65.

Schenk, G. (1997): Moss gardening: including lichens, liverworts, and other miniatures. Timber Press, Portland, Oregon

Smith, A. J. E. (2000): The moss flora of Britain and Ireland. Cambridge University Press, England

Smith, R. R. (2012): New methods in moss gardening. Chamberlain Press. 